\title{
XVIII A. LIETUVOS KARO ISTORIJOS TYRIMU APŽVALGA
}

\author{
Dr. Valdas Rakutis \\ (Vytauto Didžiojo karo muziejus)
}

İvadas

Lietuvos karo istorija XVIII a. buvo glaudžiai susijusi su Lenkijos karalystès ir visos Abiejų Tautų Respublikos karo istorija, todèl pagrindiniai darbai buvo parašyti XIX a. pabaigoje ir XX a. Lenkijoje. Lietuvos istoriografija, nors paskutiniu metu ir pasipildžiusi keletu svarbių darbų, žengia tik pirmuosius žingsnius.

XVIII a. tiek Lenkijos, tiek Lietuvos karo istorijoje nebuvo palankus laikotarpis karybai klestėti. Šiaurès karas Lietuvoje prasidèjo kruvinu vidaus karu, o kariniuose ivykiuose Lietuvos kariuomené figūruoja kaip pagalbiniai kitų kariuomenių daliniai ar prastai parengtos partizaninio tipo bajorų „,partijos“. Nepaisant ambicingų projektų, kuriais turtinga visa pirmoji XVIII a. pusé, realiai kariuomenè tebuvo šešèlis to, kas vyko už artimiausių sienų: tuo metu, kai Rusijoje, Prūsijoje ir Austrijoje augo imperijų galybé, pas mus viešpatavo apatija ir pacifizmas, trumparegiškumas ir paprasčiausias nemokšiškumas. Tik po 1764 m. buvo pradèti pirmieji žingsniai kariuomenès reformavimo, didinimo srityje, tačiau jų spartą jau reguliavo kaimynai ir mažèjančios valstybinès sienos. Tik Ketverių metų seimas trumpam atpalaidavo šiuos gniaužtus, sudarydamas sąlygas krašto karybos raidai, tačiau buvo per mažai laiko, teko patirti vieną pralaimèjimą po kito ir pagaliau 1794 m., po T. Kosciuškos sukilimo, kuris įrodẻ lenkų ir lietuvių sugebejjimą kovoti, Abiejų Tautų Respublika, o kartu ir Lietuvos Didžioji Kunigaikštystė nustojo egzistuoti Europos žemèlapyje.

\section{Darbai, skirti visam laikotarpiui. Pagalbiniai mokslai.}

Specialiai XVIII a. skirtų darbų tiek Lietuvos, tiek Lenkijos istoriografijoje beveik nėra. Jų vietoje galima paminėti platesnes karo istorijos sintezes. Lietuvos istoriografijai atstovauja S. Dirmanto straipsnis „Lietuvos kariuomenè po 1569 m.“1, kuriame kiek supaprastinai pateikiami svarbiausi Lietuvos kariuomenès raidos etapai, specifika,

\footnotetext{
${ }^{1}$ Dirmantas St. Lietuvos kariuomenè po 1569 m.//Tautos praeitis, t. II, kn. 3-4 (7-8). Chicago-Roma, 1967.
} 
tačiau viename straipsnyje pateikti poliublijinio laikotarpio kariuomenès istoriją fiziškai sunku. V. Kauklio diplominis darbas „Lietuvos kariuomene XVIII a." vertingas pasirinkta tematika, tačiau gana paviršutiniškas. Tai studentiškas bandymas, parašytas daugiau naudojantis Lenkijoje rašyta literatūra, o ne šaltiniais. Kiek geriau aprašytas Šiaurès karo ir Ketverių metų seimo laikotarpis. Pirmuoju sintetiniu veikalu reikètų laikyti Konstantino Gurskio (Konstanty Górski) Lenkijos kariuomenès rūšių istorijai skirtus darbus ${ }^{2}$, nors jie daugiau skirti Lenkijai ir gali būti panaudoti tik specifinėms problemoms tyrinèti. Idomių faktų ir minčių galima rasti ir jau istoriografijos paminklu virtusioje Tadeušo Korzono (Tadeusz Korzon) Lenkijos karu ir karybos istorijoje ${ }^{3}$. Trumpesnis ir mažiau informatyvus, tačiau prieinamas ne vien karybos istorikams Mariano Kukielio darbas „Lenkijos karybos istorijos apybraiža" reikia laikyti jau senokai, 1966 m., Varšuvoje išèjęs Lenkijos karo istorikų parengtą dvitomis veikalas „Lenkijos karybos istorijos apybraiža"5, kuriame bendrais bruožais pristatyta ir Abiejų Tautų Respublikos karybos raida XVIII a. Nemažai duomenų galima rasti ir kitoje sintetinio pobūdžio Jano Vimerio (Wimmer) knygoje „Lenkijos péstininkų istorija“, kurioje puikiai atskleistos péstininkų raidos tendencijos, kariuomenès proporcijos ir Abiejų Tautų Respublikos kariuomenès silpnumo priežastys ${ }^{6}$. Siuo metu yra ruošiama nauja ir kur kas solidesnè Lenkijos karo istorijos sintezè.

XVIII a. Lietuvos kariuomenès istorijos šaltiniai susilaukẻ labai nedaug publikacijų, dažniausiai tik tie, kurie buvo bendri Lietuvai ir Lenkijai, ir tai skirti tik antrajai šimtmečio pusei. Tai eiliniai karo istorijos šaltinių publikacijos tomai „Materiały do dziejów wojskowości“, tapę Lenkijos karo istorijos chrestomatija.

\footnotetext{
${ }^{2}$ Górski K. Historia artylerii polskiej. Warszawa, 1902; Historia jazdy polskiej. Kraków, 1894; Historia piechoty polskiej. Kraków, 1893.

${ }^{3}$ Korzon T. Dzieje wojen i wojskowości w Polsce. Lwów-Warszawa-Kraków, 1923.

${ }^{4}$ Kukiel M. Zarys historji wojskowości w Polsce. Londyn, 1948. Pakartotinai išleista Lenkijoje apie $1992 \mathrm{~m}$.

${ }^{5}$ Zarys historji wojskowości w Polsce. T. 1-2 Warszawa, 1966.

${ }^{6}$ Wimmer J. Historia piechoty polskiej do roku 1864. Warszawa,1978.
} 


\section{1697-1764 m. laikotarpis}

1697 m. kaip pradinè data pasirinkti atsižvelgiant ị Augusto II viešpatavimo pradžią, kuri žymejjo kitos užsienio politikos kryptis ir kitą valstybès raidos politiką. Tai buvo bandymas ịvesti Respublikoje absoliutinę karaliaus valdžią sekant Liudviko XIV pavyzdžiu. Tai bene mažiausiai Lietuvos istorikų tyrinètas laikotarpis, todèl ir karo istorijos tyrinejjimų būta labai nedaug. Ne ką geresnè ir Lenkijos istoriografijos padètis. Kadangi Lenkija išgyveno politinio nuosmukio laikotarpi, čia buvo maža dėmesio vertų temų, kita vertus, mažokai čia buvo reformų, ypač 1717-1764 m. laikotarpiu, todèl turime vos vieną kitą studiją ir beveik jokios šaltinių publikacijos.

\section{1. Šiaurès karas Lietuvoje (1700-1717)}

Lietuvos istoriografijai geriausiai atstovauja išeivijos istoriko ir kariškio A. Urbono darbas Didžiojo Šiaurès karo frontas Lietuvoje, leistas išeivijos „Karyje“ 1961-1963(?) metais. Autorius sugebėjo surinkti medžiagą Švedijos archyvuose ir pateikti ją logiškai, nuosekliai ir patraukliai, tačiau nemokslinis „Kario“ pobūdis neleido jam naudoti mokslinio aparato, daryti išnašų, todèl darbu sunku remtis. Šiek tiek informacijos apie Lietuvos kariuomenę Šiaurès karo išvakarèse galima rasti Gintauto Sliesoriūno disertacijos pagrindu parengtoje knygoje „ Lietuvos Didžioji kunigaikštystė vidaus karo išvakarèse: Didiku grupuočių kova 1690-1697 m.7

Bene patys geriausi ir išbaigčiausi darbai, skirti Abiejų Tautų Respublikos kariuomenei Šiaurès karo metu, parašyti J. Vimerio. Tai dvi studijos, kuriu pirmoji skirta Lenkijos ir Lietuvos kariuomenèms Šiaurès karo išvakarèse ${ }^{8}$, kita, jau monografija, - pačio karo metu ${ }^{9}$. Šiuose darbuose didžiausia dalis tenka Lenkijos kariuomenei, tačiau autorius pateikia tokius duomenis apie Lietuvos kariuomenès dydị ir savybes, kurių nèra jokiame kitame darbe, todèl šie darbai kiekvienam tyrejjui yra privalomi ir reikalingi. Tyrinètojo žinios iš ankstesnio laikotarpio padeda jam lengvai vartoti terminus, suprasti kai kurias Respublikos kariuomenės savybes, ịtraukti karinių veiksmų eigą i ka-

\footnotetext{
${ }^{7}$ Sliesoriūnas G. Lietuvos Didžioji kunigaikštystė vidaus karo išvakarèse: Didikų grupuočių kova 1690-1697 m. Vilnius, 2000.

${ }^{8}$ Wimmer J. Wojsko polskie w przededniu wojny północnej 1699-1702 // Studia i Materiały do Historii Sztuki Wojennej, t. I, Warszawa, 1954.

${ }^{9}$ Wimmer J. Wojsko Rzeczypospolitej w dobie wojny północnej 1700-1717. Warszawa, 1956.
} 
riuomenès, kaip organizmo, gyvenimą.

Tarnogrado konfederacijos ir jos kovų su Saksonijos kariuomene istorijai Lietuvoje nèra jokio straipsnio, o ir Lenkijoje yra viena studija, daugiau atskleidžianti konfederacijos genezę, nei eigą, o karo reikalams skirta palyginus nedaug. 1717 metų reformų genezė yra tyrinèta Michalo Nyčo (Michał Nycz) darbe apie karines iždo reformas1697-1717 m. ${ }^{10}$

\subsection{Lietuvos kariuomenẻ 1717-1763 (Saksų laikai)}

Tai bene mažiausiai tyrinètas laikotarpis tiek Lenkijos, tiek Lietuvos karo istorijoje, nes čia būta mažiausiai dinamikos, nedaug ivvykių, tai, be jokios abejonès, nuosmukio metai. Keletas straipsnių skirta bandymams padidinti Respublikos kariuomenę. Tai Jeronimo Kravčako (Hieronim Krawczak) apžvalginis straipsnis, skirtas Augusto III valdymo laikotarpiui $1733-1763 \mathrm{~m} .{ }^{11}$ Lietuvos kariuomenès istorijai ilgą laiką buvo skirti du Mariano J. Lecho straipsniai, vienas - viso laikotarpio svetimšalių autoramentui ${ }^{12}$, kitas skirtas tautinio autoramento kavalerijai ${ }^{13}$. Kuklų indèli yra įdèjęs ir V. Rakutis, lenkų kalba parengęs straipsni, skirtą LDK artilerijai ${ }^{14}$.

\section{1764-1795 m. laikotarpis}

XVIII a. II pusẻ buvo daug turtingesnis įvykiais laikotarpis, kurio metu vyko kariuomenès reformos, kraštą sukrète I padalijimo kataklizmas, sprendèsi esminiai valstybès gyvenimo ir gynybos klausimai, todėl ir istoriografija nepašykštèjo šiam laikotarpiui dėmesio. Turime ne tik siaurus skyrelius bendro pobūdžio veikaluose bet ir daugybę specialių monografijų ir straipsnių, skirtų platesniems ar siau-

\footnotetext{
${ }^{10}$ Nycz M. Geneza reform skarbowo - wojskowych sejmu niemego (Studium z dziejów skarbowo - wojskowych z lat 1697-1717). Pozná,,1938.

${ }^{11}$ Krawczak H. Sprawa aukcji wojska na sejmach za panowania Augusta III // Studia i Materiały do Historii Wojskowości (toliau SMHW), t. VII, cz. 2. Warszawa, 1961.

12 Autoramentas - kariuomenès dalis, suorganizuota vienodais pagrindais. Svetimšaliu autoramento daliniai susidejo iš kuopų su puskarininkių pareigybėmis, o tautiniame (lenkų) autoramente - vėliavų su draugų pareigybėmis. Lech M. J. Autorament cudzoziemski wojsk Wielkiego Księstwa Litewskiego w epoce saskiej, SMHW, t. VII, cz.1. Warszawa, 1961.

${ }^{13}$ Lech M. J. Jazda autoramentu polskiego wojsk Wielkiego Księstwa Litewskiego w dobie saskiej, tol SMHW, t. VII, cz. 2, Warszawa, 1961.

${ }^{14}$ Rakutis V. Artyleria Wielkiego Księstwa Litewskiego 1717-1764 // 2000 m. konferencijos Olštine (Lenkijos Respublika) medžiaga.
} 
resniems karo istorijos laikotarpiams, savų studijų susilaukė ir atskiros karybos istorijos problemos. Stanislovo Augusto laikai sudaro atskirą epochą, yra nemažai darbų, skirtų visam laikotarpiui, todèl juos aptarsime šiame poskyryje, nepradėję nagrinèti atskirų temų.

Bene svarbiausiu darbu apie visą laikotarpi reikia laikyti $\mathrm{T}$. Korzono Lenkijos vidaus reikalų istoriją Stanislovo Augusto Poniatovskio laikais, kuriame nemaža vietos skirta karybai ${ }^{15}$.

Didelę paramą šio laikotarpio karo istorijos tyrinėjimams turèjo antrasis kolektyvinio darbo „Abiejų tautų Respublikos karininkai 1777-1794 m. Sąrašai“16 tomas, skirtas Lietuvos Didžiosios Kunigaikštystès kariuomenei. Čia surinkta išsami informacija apie karininkus, jų tarnybos kelią, biografinius duomenis.

Atskirą grupę sudaro 1765-1795 metais veikusio Jo Karališkos malonybės Varšuvos kadetų korpusui skirti veikalai. Tyrinėjimų sąrašas iš tiesų įspūdingas. Geriausiu laikomas Kamilès Mrozovskos (Kamilla Mrozowska) darbas „Stanislovo Augusto Poniatovskio Riterių mokykla (1765-1794)“17.

\section{1. Čartoriskių reformos (1764-1768) ir Baro konfederacijos kovos (1768-1772)}

Čartoriskių reformų laikotarpis ir po jo sekusios Baro konfederacijos kovos buvo prielaidos valstybès I padalijimui arba užgrobimui. Pačios reformos kariuomenę lietė ne taip jau ir daug, tik šiek tiek pakeitè kariuomenès vadovybę, susirūpinta karių algomis, tačiau antrajame reformų etape tikrai būtų sekęs kariuomenès didinimas ir pertvarkymas. Jeigu apie bendrąsias reformas yra rašyta daug, tai Lietuvos kariuomenès reikalai yra aptarti labai paviršutiniškai, ir tai yra suprantama, nes tyrinėjant Lietuvos valstybės istorijos archyve esančią karo komisijos medžiagą daug kur teko būti pirmuoju bylą atsivertusiuoju tyrinètoju. Iki šiol pačiam straipsnio autoriui pavyko parašyti tris straipsnius, skirtus šio laikotarpio LDK kariuomenei:

\footnotetext{
${ }^{15}$ Jorzon T. Wewnętrzne dzieje Polski za Stanisława Augusta (1764-1794), badania historyczne ze stanowiska ekonomicznego i administracyjnego, t. 3, 4, Kraków; Warszawa, 1897.

${ }^{16}$ Machynia M., Rakutis V. Srzednicki Cz. Oficerowie Rzeczypospolitej Obojga Narodów 1777-1794. Spisy, t. II. Wojsko Wielkiego Księstwa Litewskiego. Kraków, 1999.

${ }^{17}$ Mrzowska K. Szkoła Rycerska Stanisława Augusta Poniatowskiego (1765-1794). WrosławWarszawa-Kraków, 1961.
} 
„Lietuvos kariuomenès reformos 1764-1776 metais“18 ir „Lietuvos Didžiosios Kunigaikštystès Karo komisija 1765-1776 m“19.

Baro konfederacijai skirta šiek tiek daugiau literatūros. Didžiausiu darbu laikomas Vladislovo Konopčinskio (Władysław Konopczyński) dvitomis veikalas”Baro konfederacija“20 ir „Žinios apie Baro konfederaciją“21. Vèlesnių tyrinètojų atsiliepimais remiantis, galima teigti, kad nors darbas atliktas didelis, daug kas pateikta netiksliai, ir V. Konopčinskio informaciją dažnai reikia tikrinti ir taisyti, todèl Lenkijoje stengtasi Baro konfederacijos istoriją perrašyti iš naujo. Lietuvos istoriografijoje darbo, skirto Baro konfederacijai, nėra, tačiau Vydas Dolinskas apie politines Baro konfederacijos ypatybes ir kai kurias kovas yra parašęs savo disertacijoje, skirtoje Simonui Kosakovskiui ${ }^{22}$.

\subsection{Pirmasis padalijimas ir $1775-1776 \mathrm{~m}$. reforma. Karo departamento laikai (1776-1788)}

Svarbiausia studija šio laikotarpio kariuomenę reikia laikyti Emanuelio Rostvorovskio (Rostworowski) straipsnị „Kariuomenès didinimo reikalas politinès situacijos kontekste prieš Ketverių metų seimą “23. Darbas išsiskiria plačiu tarptautiniu kontekstu, Respublikos kariuomenès specifika, aptariami reformų projektai ir jų vykdymo problemos. Reikšminga reikètų įvardinti Leonardo Ratajčyko monografiją „Respublikos militarinès krizės įveikimas prieš Ketverių metų seimo reformas" ${ }^{\text {“24. }}$.

\subsection{Ketveriụ metu seimas (1788-1792) ir $1792 \mathrm{~m}$. karas}

Bene žymiausias Ketverių metų seimo istoriją tyrinèjęs Lietuvos istorikas buvo Adolfas Šapoka, parašęs tik dalinai publikuo-

\footnotetext{
${ }^{18}$ Rakutis V. Lietuvos kariuomenes reformos 1764-1776 metais. Lietuvos valstybė XII-XVIII a. Vilnius, 1997.

${ }^{19}$ Rakutis V. Lietuvos Didžiosios Kunigaikštystės Karo komisija 1765-1776 m.// Karo archyvas, Nr. XV. Vilnius, 1998.

${ }^{20}$ Konopczyński W. Konfederacja Barska, t. 1-2, 1936.

${ }^{21}$ Konopczyński W. Wiadomości o konfederacji Barskiej. Poznań, 1843.

${ }^{22}$ Dolinskas V.

${ }^{23}$ Rostworowski E. Sprawa aukcji wojska na tle sytuacji politycznej przed Sejmem Czteroletnim. Warszawa, 1978.

${ }^{24}$ Ratajczyk L. Przezwyciężenie kryzysu militarnego Rzeczypospolitej przed reformami Sejmu Czteroletniego 1788-1792. Warszawa, 1975.
} 
tą $^{25}$ darbą „Lietuva reformų seimo metu“26. Pagrindinis šio darbo tikslas - atskleisti LDK kaip Respublikos tam tikros sudedamosios dalies, savitumą, Lietuvos valstybinę organizaciją ir savarankiškumo tradicijas, kurių pagrindą ir sudare kariuomenè. Tiesa, A. Šapoka nebuvo susipažinęs su Karo komisijos dokumentais, pasitenkino publikuotų šaltinių ir seimelių instrukcijų tyrimu, bet ir taip jam pavyko užčiuopti ne vieną tendenciją, reikšmingų faktų. Didelę reikšmę turi asmenybiu įvertinimas. Aptariant specifines kariuomenès problemas, žinoma, pasitaikè niekuo nepagrịstų apibendrinimų, stereotipų kartojimo, reiškiniu supaprastinimo. Istorikas neịvertino 1764-1768, 1775-1776 m. kariuomenès reformų, nematè skirtumo tarp Saksų ir Stanislovo Augusto valdymo laikotarpių.

Ypatingą vietą Lietuvos istoriografijoje, tiriant Ketverių metų seimo kariuomenès istoriją, užima Henriko Valmonto straipsnis, kuriame plačiai panaudota Lietuvos valstybès istorijos archyvo medžiaga. Straipsnyje analizuoti kariuomenès didinimo klausimai, ieškota priežasčių, trukdžiusių sukurti 100000 kariuomenę. Tenka tik apgailestauti, kad šis istorikas negalèjo tęsti pradèto darbo, nes pagal parašus archyvinėse bylose, buvo sukaupęs medžiagos kur kas išsamesniam darbui.

Lenkijos istoriografija karinėms Ketverių metų seimo reformoms skyrė ypatingą demesį. Beveik kiekviena Ketverių metų seimo, kariuomenès problema susilauke gausiu publikacijų ${ }^{27}$, kuriose susiformavo stereotipai ir jų opozicija. Visu pirma tai pasakytina apie tarptautinę Respublikos padètį. Visuose šiuose darbuose, remiantis kiekybinemis, o kartais ir kokybinemis charakteristikomis, svarstytas kariuomenès potencialo klausimas. Nepaisant tų pačių šaltinių, ịvairūs tyrinètojai laikèsi dviejų diametraliai skirtingų pozicijų: pesimistų, kuriems pradžią davė Valerianas Kalinka (Walerian Kalinka) ${ }^{28}$, ir optimistų - amžininkų ir vẻlesnių tyrinètojų, pradedant Tadeušu Korzonu (Tadeusz Korzon) ${ }^{29}$. Pesimistai manè, kad Ketverių metu

\footnotetext{
${ }^{25}$ Šapoka A. Atsakingieji Lietuvos politikos vadai Reformų seimo metu // Senove, t. 2, Kaunas, 1936.

${ }^{26}$ Šapoka A. Lietuva Reformų seimo metu. Nepublikuota daktarinė disertacija. MAB RS, F 233-117.

${ }^{27}$ Publikacijos pateiktos literatūros sąraše.

${ }^{28}$ Kalinka W. Sejm Czteroletni. Pirmasis leidimas 1879, naudotasi Warszawa, 1991 leidimu.

${ }^{29}$ Korzon T. Wewnętrzne dzieje Polski za panowaniem Stanisława Augusta Poniatowskiego (1764-1794). Badania historyczne ze stanowiska ekonomicznego i administracyjnego. T. IIIIV, Kraków-Warszawa, 1897; To paties: Dzieje wojen i wojskowośći w Polsce, Lwów-WarszawaKraków, 1923. T. III.
} 
seimo reformos, sajunga su Prūsija buvo pasmerktos iš karto, o kariuomenè, kad ir padidinta, buvo maža ir silpna. Optimistų mažuma mané, kad turimo potencialo užteko, reikejjo tik tinkamai jị panaudoti. Visai šiai diskusijai trūko gilesnès analizès, nuodugnaus kariuomenès archyvo studijavimo, kuri pradejjo Adamas Volanskis (Wolański), pratęsé Emanuelis Rostvorovskis (Rostworowski), Leonardas Ratajčykas (Ratajczyk), šiek tiek Jeržis Lojekas (Jerzy Łojek) ir kiti tyrinètojai, kuriuos ir norètųsi atskirai aptarti. A. Volanskio „Lenkijos-Rusijos karas 1792 m. “30 yra unikalus, labai skrupulingas darbas, kuriame išnagrinèta daug ne tik paties karo, bet ir kariuomenès problemų. Šis istorikas pakankamai tiksliai įvertino kiekybinius Lenkijos ir Lietuvos kariuomeniu rodiklius, pateike savaji kokybini kariuomenès įvertinimą, apibūdino kai kuriuos vadus ir institucijas. Didelè dalis darbe panaudotų dokumentų žuvo pačioje I pasaulinio karo pabaigoje, todèl šią studiją galima naudoti kaip šaltinị ${ }^{31}$. Struktūriniu požiūriu darbas svarbus ir tuo, kad jị sudaro du tomai, kurių pirmasis skirtas Lenkijos Karalystès, o antrasis Lietuvos kampanijoms. Tai autoriui leido ịsigilinti ị Lietuvos ir Lenkijos kariuomenių specifiką. Darbas per ištisus šimtą metų mažai tepaseno. Žiūrint iš šios dienos pozicijų, prastokos schemos ir trūksta žemèlapių, tačiau, tiesą sakant, vargu ar būtų galima ką nors iš esmès pridėti neturint naujų šaltinių. Galima tik polemizuoti, ar buvo teisus A.Volanskis, vienpusiškai palaikydamas „sveikają“ reformatorių pusę, kuri ryžosi per trumpą laiką „,pasivyti“ labai toli pažengusias valstybes. Galbūt per daug buvo ieškoma prarastų šansų spėliojant, kas būtų, jeigu būtų, bet tyrinėjant toki karą, tai neišvengiama blogybė: kitaip sunku būtų ịvertinti priimtus sprendimus.

Tarpukario Lenkijoje mūsų tematika domètasi mažiau, pasirodẻ tik vienas kitas sintetinio pobūdžio veikalas, straipsniai pusiau populiariuose leidiniuose. Išskirti reikètų Jano Gergelevičiaus (Giergelewicz) darbus, skirtus inžinierių korpusams ${ }^{32}$ ir Pranciškaus Giedroico (Franciszek Giedroyc), skirtą sveikatos tarnybai ${ }^{33}$, taip pat ke-

\footnotetext{
${ }^{30}$ Wolanski A. Wojna polsko-rosyjska 1792 r. Pirmasis leidimas, dar su Soplicos slapyvardžiu, išèjo 1905 m. Krokuvoje (T. I. Kampania Koronna) ir 1922 m. Poznanejje (T. II. Kampania Litewska). Darbe naudotasi naujausiu leidimu Warszawa, 1996.

${ }^{31}$ Kaip pavyko nustatyti, dauguma tariamai žuvusių dokumentų, buvusių nuorašais, išliko Lietuvos Karo komisijos fonde Senụjų aktų fondų grupejje Lietuvos valstybès istorijos archyve. ${ }^{32}$ Daugiausiai naudotasi: Giergielewicz J. Zarys historii korpusów inżynierów w epoce Stanisława Augusta. Warszawa, 1933.

${ }^{33}$ Giedrojć F. Służba zdrowia w dawnym Wojsku Polskim. Warszawa, 1927.
} 
letą biografijų, paskelbtų „Lenkijos biografiniame žodyne“ ir atskirais straipsniais ${ }^{34}$, visi jie atskleide siaurų kariuomenès reformavimo sričių padèti, surinko daugiau biografinių žinių. Iš jaunesnès kartos atskiro paminèjimo verti Emanuelio Rostvorovskio (Emmanuel Rostworowski) darbai, pasižymintys požiūrių naujumu, nepaprasta erudicija, probleminiu dèstymu ir minties laisvumu ${ }^{35}$.

Svarbiausia istoriografine pozicija, analizuojant kariuomenès būklę, reikètų laikyti Leonardo Ratajčyko (Ratajczyk) straipsnius ir iš ju padarytą studija „Respublikos kariuomenè ir gynybos sistema 1788-1792 m“36. Darbe buvo panaudota daug šaltinių, susipažinta su visais svarbiausiais archyvais, kartu ir LDK Karo komisijos dokumentais, saugomais Lietuvos valstybés istorijos archyve. Autorius, ko gero, ėmèsi per daug sunkaus uždavinio, norėdamas viename darbe sudeti ir naujus tyrinejimus, ir sintetini apibendrinimą, realiai nesugebedamas padaryti nei vieno, nei kito. Savo darbe jis per daug pasikliovė autoritetais, vengè drąsesnių pasisakymų, per daug izoliavosi nuo politinių ivvykių, nejaute visuomeninio gyvenimo pulso, ir tai daro knygą perdèm akademišką blogaja prasme. Yra priekaištu ir darbo metodikai. Fiziškai negaleddamas ịvertinti visos faktinès informacijos, L. Ratajčykas pateikè momentinius rezultatus pasirinktuose chronologiniuose taškuose. Tokiu metodu suformuotas vaizdas netinkamas platesniems apibendrinimams, o juos darant pateikiamos nepakankamai pamatuotos išvados.

Kšištofas Baueris (Krzysztof Bauer) paraše 1792 metų karo sintezę, tačiau dèl mažos darbo apimties pasiekè paviršutiniškų rezultatų. Tik vienas kitas sakinys pasakẻ ką nors nauja, darbe nesugebèta pralenkti A. Volanskị ${ }^{37}$.

Jeržis Lojekas (Jerzy Łojek) garsus netradiciniais požiūriais i XVIII a. II pusès politinius ir visuomeninius įvykius. Jo argumentai

\footnotetext{
${ }^{34}$ Buniewiczówna J. Fryderyk Wilhelm von Cronemann, generał major artylerii Wielkiego Księstwa Litewskiego (1739-1799).//Przegląd arttyleryjski. R. 1937.

${ }^{35}$ Rostworowski E.Hugo Kołłątaj wobec zagadnienia obywatelskiej siły zbrojnej (1784-1793). Atskiras spaudas Jogailos bibliotekoje Krokuvoje; To paties Ostatni król Rzeczypospolitej, geneza i upadek Konstytucji 3 Maja. Warszawa, 1966; To paties Sprawa aukcji wojska na tle sytuacji politycznej przed sejmem Czteroletnim. Warszawa, 1957; To paties Sprawa milicji mieszczańskiej w ostatnim roku Sejmu Czteroletnego // Przegląd Historyczny R. 1955. s. 561-584; To paties Sprawa zaplecza przemysłowego dla armii na sejmie Czteroletnim//Kwartalnik Historyczny R. 1956. Nr. 4-5, s. 44-63; To paties Z dziejów genezy targowicy - Sprawa kawalerji narodowej w dobie Sejmu Czteroletnego // Przegląd Historyczny R. 1954. s. 14-35.

${ }^{36}$ Ratajczyk L.Wojsko i obronność Rzeczypospolitej 1788-1792. Warszawa, 1975.

${ }^{37}$ Bauer K.Wojna w obronie konstytucji 3 maja i niepodległości Rzeczypospolitej.
} 
dažnai pasirodo nepakankamai pagrịsti, išvados per daug kategoriškos, tačiau tokio pobūdžio knygos ir straipsniai neleidžia užmigti autoritetų pavėsyje, verčia iš naujo tikrinti, atrodytų, aiškius dalykus ir tokiu būdu stumia mokslą i priekị ${ }^{38}$. J. Lojekas ieškojo argumentų tezei, kad 1792 m. karą Respublika galejjo laimèti ir su turimu potencialu. Toks bandymas sudare atsvara V. Kalinkos mokyklai, kuriai visi bandymai kovoti prieš Rusijos ịtaką atrode pasmerkti. Norèdamas argumentuoti savo tezę, J. Lojekas atliko optimistinę Respublikos kariuomenès ir jos galimybiu analizę.

Su S. Žychlinskio darbu, skirtu Ketverių metų seimo reformoms $^{39}$, teko susipažinti fragmentiškai. Sprendžiant iš pabaigos, plano ir literatūros sąrašo, tai Respublikos kariuomenei skirtas darbas, paremtas literatūra ir skelbtais šaltiniais, susisteminantis iki šiol žinomus dalykus.

\subsection{Torgovicos konfederacijos ir Gardino seimo laikai (1792-} 1794). T. Kosciuškos sukilimas ir Lietuvos kariuomenès likvidavimas (1794-1795)

Toks šio poskyrio temos formulavimas gal kiek glumina skaitytoją, glausdamas kelis tarsi skirtingus laikotarpius, tačiau dauguma tyrinètojų, siekdami apžvelgti T. Kosčiuškos sukilimo genezę, studijuoja 1792-1794 m. ìvykius, buvusius iki sukilimo pradžios. Lietuvos istoriografijoje pagrindiniu tyrinètoju reikia ịvardyti neseniai mirusį Rimantą Jasą, kuris parašè keletą straipsnių Lietuviškajai tarybinei enciklopedijai, paskelbè kelis straipsnius, tačiau pagrindinio savo veikalo - Kosciuškos sukilimui Lietuvoje skirtos knygos taip ir neparašè, surinkta medžiaga ir kai kurios pradètos dalys tebelaukia savo tyrinètojo Mokslų akademijos bibliotekos rankraštyne.

Lenkijos istoriografija šiam laikotarpiui skyre per šimtą mokslinių pozicijų, yra atskirai tirta ir aprašyta Janušo Vojtasiko (Janusz Wojtasik) straipsnyje „Kosciuškos sukilimo istoriografija“, įdètame tam pačiam sukilimui skirtoje sintezeje ${ }^{40}$. Čia aptarsime tuos darbus, kurie skirti tik Lietuvos įvykiams.

\footnotetext{
${ }^{38}$ Lojek J. Armia sejmu Czteroletniego // Wokól sporów i polemik. Lublin, 1979.

${ }^{39}$ Żychliński S. Reforma wojskowa na sejmie czteroletnim. Szczecin, 1992.

${ }^{40}$ Wojtasik J. Historiografia powstamia kościuszkowskiego//Powstanie kościuszkowskie 1794.

Dzieje militarne. T. I, Warszawa, 1994.
} 
Jau iki I pasaulinio karo pasirodė nemažai leidinių, skirtų sukilimui Lietuvoje. Pradžioje tai buvo biografinio pobūdžio darbai, parašyti iš tam tikros asmeninès korespondencijos ar tuo metu tyrinètojui prieinamos archyvinio fondo dalies. Sukilimo genezei atskleisti buvo parašyta Mariano Dubeckio (Dubiecki) knyga apie LDK stovyklininką Karolị Prozorąa ${ }^{41}$, vieną aktyviausių Lietuvos sukilimo veikejų. Svarbių faktų galima rasti Vladislovo Smolenskio (Władysław Smoleński) „Targovicos konfederacijoje“42.

1917 m. buvo švenčiamos 100-tosios T. Kosciuškos mirimo metinès. Ta proga pasirodè bent 200 straipsnių, tarp jų keletas labai svarbių darbų, paminètinas Henriko Moscickio darbas "Generolas Jasinskis ir Kosciuškos sukilimas" 43 , tapęs gausių T. Kosciuškos sukilimui skirtų darbų, kuriuose būtų gilinamasi ị Lietuvos reikalus, pagrindu. Tuo pačiu metu prasidejo garsioji diskusija apie T. Kosciuškos vaidmenị sukilime, kuri pastūmejo Lenkijos istorikus labiau domètis 1794 m. îvykiais. Kariniams reikalams tyrinèti daug padejo Vaclavo Tokažo (Wacław Tokarz) darbai, pasiūlę ištobulintą šio sukilimo tyrinèjimo metodiką, kurios pagrindu susikūrè visa tyrinètoju mokykla. Lietuvos ịvykiams iš jų daugiausiai demesio skyre Leonidas Žytkovičius (Żytkowicz), kuris parašè keletą mūsų tematikai aktualių darbų: „Lietuva ir Karalyste 1794 m.“, „Repnino valdžia Lietuvoje 1794-97 metais“, „LDK iždo santykiai Kosciuškos sukilimo laikotarpiu“ ir „Apie Jasinskio santykius su Torgovicos konfederacija“44. Inžinierių korpuso veiksmams, taip pat ir LDK, savo tyrinejimus skyrė Janas Gergelevičius (Giergielewicz) ${ }^{45}$, atskirą darbą yra pateikęs ir Janušas Ivaškevičius (Janusz Iwaszkiewicz) ${ }^{46}$.

\footnotetext{
${ }^{41}$ Dubiecki M. Karol Prozor, oboźny w W. Ks. Litewskim. Przyczynek do dziejów powstania kościuszkowskiego. Kraków, 1897.

${ }^{42}$ Smoleński W. Konfederacja targowicka. Kraków, 1903.

${ }^{43}$ Moscicki H. Generał Jasiński i powstanie Kościuszkowskie. Warszawa, 1917.

${ }^{44}$ Żytkowicz L. Litwa i Korona w r. 1794 // Ateneum Wileńskie, 1937, R. XII; To paties: Rządy Repnina na Litwie w latach 1794-1797, Wilno, 1938; to paties: Stosunki skarbowe W. Ks. Litewskiego w dobie insurekcji kościuszkowskiej // Ateneum Wileńskie, 1935, R. X, s. 97160; To paties: Ze stosunków Jasińskiego z konfederacją targowicką // Ateneum Wileńskie, 1938, R. XIII.

${ }^{45}$ Giergelewicz J. Zarys historii korpusu inźynierów w epoce Stanisława Augusta. Warszawa, 1933; To paties Organizacja wojsk technicznych w powstaniu kościuszkowskim// Przegłąd Historyczno-Wojskowy, 1930, t. III, s. 127-144.

${ }^{46}$ Przyczyńki do powstania kościuszkowskiego na Litwie//Ateneum Wileńskie, 1923, R. I, nr. 1.
} 
Po II pasaulinio karo Lenkijos istoriografiją buvo prislėgusi Stalino ideologijos girnapusé, todèl objektyvūs darbai pasirodyti negalëjo, pavyko išleisti tik II Kosciuškos sukilimo aktų tomą, rengtą karo metais. Po 1756 metų Kosciuškos sukilimo tematikos ėmèsi Stanislavas Herbstas (Stanisław Herbst), suteikęs šio laikotarpio tyrimams naują kokybini postūmị. Nors Herbsto darbai nebuvo skirti Lietuvos tematikai, šio darbo ėmèsi jo mokiniai, kurie buvo rengiami specialiame seminare. Vienas iš jų - Zdzislavas Sulekas (Zdzisław Sułek) išleido knygą „Jokūbo Jasinskio sąmoksla“47, skirtą pasirengimo sukilimui Lietuvoje istorijai. Joje gilinamasi tiek i Targovicos konfederacijos politikos kariuomenès atžvilgiu problemas, tiek ị sukilimo organizavimą ir karininkų dalyvavimą rengiant sukilimą. Šio darbo privalumas - Karo komisijos fondo iš Lietuvos valstybès istorijos archyvo ir kitų šaltinių naudojimas, leidęs naujai pažvelgti ị Lietuvos sukilimo genezę ir veikiančius asmenis. 1957-1967 pasirodè keletas dokumentų publikacijų, turẻjusių ịtakos naujiems darbams, skirtiems Lietuvos ivykiams, atsirasti. Tai Jano Dihmo parengti J. U. Nemcevičiaus (Niemcewicz) ${ }^{48}$ J. Koveckio (Kowecki) parengti A. Trembickio (Trębicki) ${ }^{49}$ atsiminimai, Z. Suleko parengti Slaptosios Vilniaus deputacijos 1794 m. protokolai ${ }^{50}$.

Lenkijos karo istorikai, siekdami kuo išsamiau apibūdinti visą sukilimo eigą ir ịvairias problemas, suvoke netolygiai mažiau ištirtą LDK sukilimą, todèl paskutini dešimtmetị Herbsto mokiniai Tadeušas Ravskis (Tadeusz Rawski), Veslavas Majevskis (Wiesław Majewski) ir kiti sukilimui Lietuvos teritorijoje skyrè vis daugiau dėmesio. Lenkijos karo istorijos instituto tritomis veikalas „Kosciuškos sukilimas. Militarine istorija “51, sudarytas T. Ravskio ir skirtas 200-osioms sukilimo metinèms, yra šios temos tyrinètojui pagrindinè knyga. Nors kariniams aspektams skirti tik pirmieji du tomai, darbas parašytas profesionaliai, tinkamai atstovaujant Lietuvos reikalams ir išlaikant retą lenkų istorikų darbams Lenkijos-Lietuvos paritetą, yra puikios schemos. Tai, ži-

\footnotetext{
${ }^{47}$ Sułek Z. Sprzysiężenie Jakuba Jasińskiego.

48 Julian Ursin Niemcewicz. Pamiętniki czasów moich, t. 1-2. Pierwsze wydanie według obszerniejszej wersji rękopisemnej. Tekst opracował i wstępem poprzedił Jan Dihm. Warszawa, 1957.

${ }^{49}$ Antoni Trębicki. Opisanie sejmu estraordynaryjnego podziałowego roku 1793 w Grodnia. O rewolucji roku 1794. Opracował, wstępem poprzedził J. Kowecki. Warszawa, 1967.

${ }^{50}$ Sułek Z. Protokoły Deputacji Tajnej Wileńskiej 1794, cz. I, II, //Studia i Materiały do historji wojskowości, t. XII, cz. I. II, Warszawa, 1967.

${ }^{51}$ Powstanie Kościuszkowskie 1794. Dzieje militarne, t. 1, Warszawa, 1994, t. 2.
} 
noma, ne paskutinis žodis T. Kosciuškos sukilimo istoriografijoje, bet tinkamas XIX-XX a. darbų apibendrinimas.

Rusijos istoriografija daugiau publikavo šaltinius, nei èmèsi sintetinių darbų, be to, ir paskutiniuju metų publikacijos nėra žinomos, todèl šioje apžvalgoje nebus analizuojamos.

\section{Neištirtos temos}

Apžvelgę istoriografijos tyrimus, galime pastebėti, kad didžiausią problemą kelia tie laikotarpiai ir tos temos, kurių archyvai nėra lokalizuoti vienoje vietoje kompaktiškais fondais arba tie fondai nèra pakankamai lengvai prieinami tyrinètojams.

Šiaurès karo laikotarpis, kurio dokumentų fondų beveik nèra archyvuose, vos pavieniai ir ne patys svarbiausi dokumentai. Gali būti, kad jų niekas ir nevedè, veikiant nereguliaraus pobūdžio lietuviškiesiems daliniams. Čia daugiau gali padèti Švedijos ir Rusijos archyvai. Reikètų darbų šiomis temomis:

1. Lietuviškieji daliniai Šiaurès karo metu (1700-1709).

2. Lietuvos kariuomenès atkūrimas ir padidinimas nuo Poltavos mūšio $1709 \mathrm{~m}$. iki nuolatinès kariuomenès atsiradimo $1717 \mathrm{~m}$.

Vertetų naujai perrašyti darbą, kurio èmėsi A. Urbonas „Didžiojo Šiaurès karo frontas Lietuvoje”, ittraukiant mokslinị aparatą ir naudojant daugiau naujausios literatūros. Vertètų sužinoti, ar nèra išlikusio A.Urbono archyvo, kuris palengvintų ši darbą. Reikètų parašyti bendrają Šiaurès karo istoriją, daugiau dėmesio skiriant Lietuvos ir aplinkinio regiono istorijai, mažiau dėmesio skiriant Danijos ir Rusijos kampanijoms bei ivykiams po $1709 \mathrm{~m}$.

1717-1764 m. laikotarpis yra ištirtas geriau, tai ir padaryti lengviau, nes tokị ilgą laiką nesikeitè kariuomenès sistema. Tyrimų reikalauja karininkų korpusas. Didelị apibendrinantị darbą, kuriame būtų atskleista karininkų karjera, būtų galima parašyti tik po daug darbo reikalaujančiu tyrimų, naudojant valdovo suteiktų patentų medžiagą ir kitas priemones, panaudotas Česlovo Šrednickio (Czesław Srzednicki) grupès darbe „Abiejų Tautų Respublikos karininkai. Sąrašai" ${ }^{\text {"52 }}$, tačiau pirmiausia reikia tiksliai nustatyti, kuriose Lietuvos Metrikos aktuose ši medžiaga. Reikètų kelių darbų, skirtų reformų projektams, etmonų veiklai ir Lietuvos teritorijoje vykusiems kariniams veiksmams ar su jais susijusiems ịvykiams: 1733-1737 m. Len-

${ }^{52} \mathrm{Zr}$. Išnašą. 
kijos ịpėdinystės karui, Septynerių metų karui ir jų ryšiams su Lietuva, 1763-1764 m. tarpuvaldžio kovoms. Žinant, kad yra išlikęs kunigaikščių Radvilų archyvas, būtų galima parašyti kapitalinị darbą apie Radvilų miliciją XVIII a.

1764-1773 m. laikotarpis yra aktyviau tyrinejjamas mano ir artimiausiu metu turetu pasipildyti straipsniais ar net knyga Lietuvos kariuomene Čartoriskiu reformu metu 1764-1768 m., savojo tyrinètojo laukia kompaktiški fondai Varšuvoje esančiame Vyriausiame senujjų aktų archyve (AGAD). Reikètų ištirti ir karininkų korpusą. Vis dar neturime vientiso darbo apie Baro konfederaciją, todèl reikètų parašyti visapusišką knygą, kurioje būtų kalbama apie karo reikalus.

1775-1776 m. kariuomenès reformos dar nèra pakankamai ištirta problema, nors ir pajudinta mano magistro darbe „Lietuvos Didžiosios kunigaikštystès reforma 1764-1788 m.“ Jas galima tirti atskirai, tačiau geresnis būtų darbas, skirtas Lietuvos kariuomenei nuo Baro konfederacijos iki Ketverių metų seimo, tada būtų galima apimti daugiau problemų ir išsamiau jas aprašyti, nes nèra tikslinga atskirai tirti 1776-1788 metų laikotarpi, kurio metu didelių pokyčiu nevyko. Taip pat verta versti i lietuvių kalba L. Ratajčyko knygą „Militarinès krizès įveikimas prieš Ketverių metų seimo reformas“.

Ketverių metụ seimo laikotarpis šiuo metu santykinai gerai ištirtas, trūksta tik kariuomenès ryšių su visuomene. 1792 m. karą šiuo metu tyrinèti netikslinga, geriau išversti ị lietuvių kalbą A. Volanskio knygą „Lenkijos-Rusijos karas 1792 m.“ Praverstų XVIII a. II pusès karinių ịvykių schemų iš žemèlapių atlasas.

1792-1794 m. laikotarpiui reikètų keleto straipsnių. Tyrinètojo laukia Lietuvos generalinès konfederacijos politika kariuomenès atžvilgiu 1792-1794 m., gegužès 3 d. konstitucijos šalininkų veikla kariuomenèje prieš Kosciuškos sukilimą ar bendro pobūdžio darbas, skirtas LDK kariuomenès istorijai nuo $1792 \mathrm{~m}$. karo iki $1794 \mathrm{~m}$. Kosciuškos sukilimo.

Kosciuškos sukilimui reikètų vienos geros studijos, kurią pradejo R. Jasas, skirtos 1794 m. T. Kosciuškos sukilimui Lietuvoje, jo militariniams aspektams. 


\section{IŠVADOS}

Lietuvos karo istorija XVIII a. yra ištirta labai netolygiai. Jeigu amžiaus pabaiga turi keletą gerų studijų, puikų Lenkijos istoriografijos kontekstą ir parengtus tyrinètojus, tai amžiaus pradžia ir vidurys neturi nei vieno, nei kito. Didelis dėmesys turi būti skirtas pagalbinès medžiagos rengimui, privačių archyvų tyrimams, taip pat reikia daugiau visuotinės istorijos darbų, apibūdinančių situaciją Lietuvos ir Lenkijos kaimynysteje, ypač svarbūs palyginamieji tyrimai. Taip pat perspektyviai atrodo bandymai gilintis ị socialinius Abieju Tautų Respublikos santykius, ieškoti valstybès ir kariuomenès silpnumo šaknų vidiniuose Respublikos partijų ir grupuočių santykiuose bei užsienio valstybių politikoje. XVIII a. tyrinėtojai turi palaikyti artimus kontaktus su Lenkijos, Baltarusijos, Ukrainos tyrinètojais, nes tyrimo objektas yra iš esmès ta pati kariuomenė ir ta pati karyba.

İteikta 2002-09-03 


\title{
RÉSUMÉ
}

\section{Revue des recherches sur l'histoire militaire de la Lituanie au XVIIIe siècle}

\author{
Dr. Valdas Rakutis \\ Musée de la Guerre Vytautas le Grand
}

L'histoire militaire de la Lituanie au XVIIIe siècle est étudiée de faēon trčs irréguličre. Si la fin du siècle a plusieurs bonnes études, un bon contexte historiographique polonais et des chercheurs formés, le début et le milieu du siècle n'ont ni l'un, ni l'autre. Une grande attention doit źtre portée à l'organisation de sources auxiliaires et aux études des archives privées, il faut aussi plus de travaux sur l'histoire universelle, caractérisant la situation dans le voisinage polono-lituanien, les études comparatives sont très importantes. Les tentatives d'approfondir les relations sociales de la République des Deux Peuples et de rechercher les racines de l'affaiblissement de l'Etat et de l'armée dans les relations internes des groupes et des partis de la République ainsi que dans la politique des Etats étrangers semblent aussi avoir des perspectives. Les chercheurs du XVIIIe siècle doivent maintenir des contacts étroits avec les chercheurs polonais, biélorusses et ukrainiens, car l'objet d'étude est en fait la mźme armée et le mźme art de la guerre. 